\title{
PENGARUH GURU MATEMATIKA IDOLA TERHADAP HASIL BELAJAR SISWA SECARA TIDAK LANGSUNG MELALUI MOTIVASI BELAJAR MATEMATIKA KELAS X SMA MUHAMMADIYAH 1 SURABAYA
}

\author{
Sefti Ika Wulansari ${ }^{1}$, Chusnal Ainy ${ }^{2}$, Endang Suprapti ${ }^{3}$ \\ Program Studi Pendidikan Matematika, FKIP UMSurabaya \\ sefti.light@gmail.com
}

\begin{abstract}
ABSTRAK
Matematika masih menjadi pelajaran yang tidak diminati bagi sebagian besar siswa. Sehingga siswa kurang memiliki motivasi untuk mempelajarinya. Guru sebagai salah satu elemen utama yang berperan dalam kegiatan pembelajaran di kelas menjadi komponen penting sebagai pembangkit motivasi belajar siswa. Dengan menjadi sosok idola bagi para siswanya, prilaku guru seperti rasa cintanya terhadap matematika, semangatnya mengerjakan soal matematika dan prestasi yang ia dapat akan diaplikasikan siswa kedalam dirinya. Oleh karena itu penelitian ini bertujuan untuk mendeskripsikan Pengaruh Guru Matematika Idola Terhadap Hasil Belajar Siswa Secara Tidak Langsung Melalui Motivasi Belajar Siawa Kelas X SMA Muhammadiyah 1 Surabaya”. Dengan metode yang di gunakan adalah metode deskriptif kuantitatif, karena penelitian ini akan menganalisa pengaruh yang diberikan dari Guru Matematika Idola di kelas X-1 hasil belajar siswa melalui motivasi belajar. Dari hasil penelitian menunjukkan bahwa guru matematika idola berpengaruh terhadap hasil belajar siswa melalui motivasi belajar matematika sebesar $71.4 \%$ dan sisanya $38.6 \%$ dijelaskan faktor lain diluar model penelitian.
\end{abstract}

Kata Kunci: Guru Matematika Idola, Hasil Belajar, Motivasi belajar

\begin{abstract}
Mathematics becomes undesirable lesson for most of the students. Teachers as one of the main element who play the role of learning activities in the class are become important component as students' motivation initiator. By being a role model for the students, the teacher's behavior as his love of math, their motivation to do math and achievement which they get will be applied by the students into their selves. Therefore, this research aims to describe the Influence of Mathematics Teacher Idol to indirect Students' learning outcome through the students' learning motivation at grade X Muhammadiyah 1 Senior High School Surabaya. The method used in this research is descriptive quantitative method, because this research will analyze the impact of the Mathematics Teacher idol given in grade X-1 related to students' learning outcomes through learning motivation. The results showed that the mathematics teacher idol effect on students' learning outcomes through the motivation to learn mathematics as $71.4 \%$ and the remaining $38.6 \%$ explained other factors beyond the research model.
\end{abstract}

Keywords: Learning Outcomes, Learning Motivation, Mathematics Teacher Idol.

\section{PENDAHULUAN}

Oemar Hamalik (2000: 27) menyatakan bahwa kepribadiaan guru sebagai faktor yang sangat penting dan sangat berpengaruh terhadap siswa, yaitu: Banyak sekali percobaan dan pengamatan belajar menegaskan fakta bahwa muridmurid belajar dari guru sebaik apa yang dikatakan guru. Murid-murid menyerap 
sikapnya, mereka menggambarkan sopan santunya, mereka ambil keyakinanya, mereka tiru kelakuanya, dan mereka catat pernyataan-pernyataannya. Pengalaman menerangkan fakta bahwa masalah-masalah seperti motivasi, disiplin, tindakan sosial, motivasi sisiwa, dan semua hal tersebut, keinginan yang berkesinambungan untuk belajar yang berpusat pada kepribadian guru.

Oleh karena itu guru hendaknya bisa dijadikan contoh dalam perilaku keteladanan yang selalu tampil menyenangkan dalam proses pembelajaran. Guru pun harus mampu memerankan diri sebagai aktor dalam berbagi keadaan yang berbeda. kadang-kadang guru dituntut menjadi orang tua, teman, penasehat, dan pengembang kreatifitas. Semua itu akan tercapai apabila guru bisa menjadi sosok idola bagi anak didiknya. Karena dengan menjadi idola bagi anak didik maka secara tidak langsung anak didik akan meniru atau meneladani serta mengaplikasikan perilaku guru idolanya ke dalam dirinya.

Hal inilah yang kemudian menuntut seorang guru untuk selalu memunculkan ide-ide kreatif yang dapat membangkitkan semangat belajar anak didiknya dengan cara membekali diri dengan kompetensi personal pada diri seorang guru. Salah satu kompetensi personal tersebut ialah kemampuan guru dalam menjadikan dirinya sebagai idola bagi anak didiknya. Dengan menjadi idola bagi anak didiknya, seorang guru diharapkan mampu memberikan rasa aman, nyaman, demokratis dalam proses pembelajaran sehingga dapat membangkitkan semangat siswa untuk senantiasa belajar. Semangat belajar yang tinggi pada siswa akan membantu guru dalam menciptakan suatu proses pembelajaran yang efektif sehingga tercapai tujuan pembelajaran yang diharapkan.

SMA Muhammadiyah 1 Surabaya merupakan sekolah yang sangat memperhatikan hasil belajar siswanya. Siswa secara keseluruhan diharapkan dapat memenuhi KKM yang telah ditetapkan sekolah. Sebagian besar siswa masih kurang menggemari mata pelajaran matematika. Namun demikian ada beberapa siswa yang mampu mendapatkan nilai tinggi. Beberapa siswa yang mendapatkan nilai matematika tinggi menjadi bintang kelas. Salah satu penyebabnya karena guru matematika merupakan idola beberapa siswa tersebut. 
Adapun tujuan dalam penelitian ini untuk menganalisis:

1. pengaruh yang signifikan variabel guru matematika idola terhadap motivasi belajar matematika?

2. pengaruh yang signifikan variabel guru matematika idola terhadap hasil belajar siswa?

3. pengaruh guru matematika idola terhadap hasil belajar siswa melalui motivasi belajar matematika?

Dengan hipotesis:

H1: Terdapat pengaruh yang signifikan variabel guru matematika idola terhadap motivasi belajar matematika di kelas X-1 SMA Muhammadiyah 1 Surabaya

$\mathrm{H} 2$ : Terdapat pengaruh yang signifikan variabel motivasi belajar terhadap hasil belajar siswa di kelas X-1 SMA Muhammadiyah 1 Surabaya

H3: Terdapat pengaruh guru matematika idola terhadap hasil belajar siswa di kelas X-1 SMA Muhammadiyah 1 Surabaya

\section{METODE PENELITAIAN}

Penelitian ini merupakan penelitian deskriptif kuantitatif. Instrumen yang digunakan berupa angket dan pedoman wawancara. Intrumen lainya berupa data hasil belajar siswa semester I yang didapat dari arsip nilai siswa kelas $\mathrm{x}-1$ milik guru kelas. Adapun teknik untuk memperoleh datanya membuat angket dengan kisi-kisi sebagai berikut:

Tabel 1. Angket Guru Idola

\begin{tabular}{|c|c|c|c|c|c|c|}
\hline \multirow{2}{*}{ Variabel } & \multirow{2}{*}{ Indikator } & \multirow{2}{*}{ Nomor angket } & \multicolumn{4}{|c|}{ Penskoran } \\
\hline & & & SS & $\mathbf{S}$ & TS & STS \\
\hline \multirow{11}{*}{$\begin{array}{l}\text { X (Persepsi } \\
\text { siswa terhadap } \\
\text { guru matematika } \\
\text { di kelas) }\end{array}$} & Memiliki Modal sebagai guru & 1 dan 2 & 4 & 3 & 2 & 1 \\
\hline & Memperhatikan Penampilan & 3 dan 4 & 4 & 3 & 2 & 1 \\
\hline & Pripare baik-baik sebelum action & 5,6 dan 7 & 4 & 3 & 2 & 1 \\
\hline & Kreatif & $8,9,10$ dan 11 & 4 & 3 & 2 & 1 \\
\hline & Menggunakan hati & 12 & 4 & 3 & 2 & 1 \\
\hline & Menjadi teman siswa & 13 & 4 & 3 & 2 & 1 \\
\hline & Menunjukkan keteladanan & 14 & 4 & 3 & 2 & 1 \\
\hline & Tidak sok tahu & 15 & 4 & 3 & 2 & 1 \\
\hline & Menghargai dan Menghormati Siswa & 16 & 4 & 3 & 2 & 1 \\
\hline & Lembut Tapi Tegas & 17 & 4 & 3 & 2 & 1 \\
\hline & Mengerti Kebutuhan siswa & 18 dan 19 & 4 & 3 & 2 & 1 \\
\hline
\end{tabular}


Sefti Ika Wulansari ${ }^{1}$, Chusnal Ainy ${ }^{2}$, Endang Suprapti ${ }^{3}$

Tabel 2. Angket Motivasi

\begin{tabular}{|c|c|c|}
\hline Variabel & Indikator & Nomor angket \\
\hline \multirow[t]{2}{*}{$\mathrm{Y}_{2}$ (Motivasi belajar siswa) } & $\begin{array}{l}\text { Indikator Motivasi Intrinsik: } \\
\text { Kebutuhan } \\
\text { Ketertarikan } \\
\text { Keingintahuan } \\
\text { Kesenangan }\end{array}$ & $\begin{array}{l}1,2,3, \text { dan } 4 \\
5,6 \text { dan } 7 \\
8,9,10, \text { dan } 11 \\
12,13,14,15 \text {, dan } 16\end{array}$ \\
\hline & $\begin{array}{l}\text { Indikator Motivasi Ekstrinsik: } \\
\text { Hadiah }\end{array}$ & 17, 18 dan 19 \\
\hline
\end{tabular}

Dimyati dan Mudjiono: 2009 (diolah oleh peneliti)

Tabel 3. Pedoman Penskoran Angket Motivasi

\begin{tabular}{|c|l|c|c|}
\hline \multirow{2}{*}{ No. } & \multirow{2}{*}{ Hasil Angket } & \multicolumn{2}{|c|}{ Skor } \\
\cline { 3 - 4 } & & Pernyataan Positif & Pernyataan Negatif \\
\hline 1 & Sangat Tidak Setuju & 1 & 4 \\
\hline 2 & Kurang Setuju & 2 & 3 \\
\hline 3 & Setuju & 3 & 2 \\
\hline 4 & Sangat Setuju & 4 & 1 \\
\hline
\end{tabular}

Sugiyono (2011:93)

Skor tiap item indikator dijumlahkan. Untuk meliat keberhasilan indikator, skor total dikonversikan ketabel berikut ini:

Tabel 4. Kriteria skor rata-rata

Angket Guru Matematika Idola dan Motivasi Belajar Matematika

\begin{tabular}{|c|c|c|}
\hline No. & Skor & Kriteria \\
\hline 1. & $76 \leq$ Rata - rata $<95$ & Sangat Positif \\
\hline 2. & $57 \leq$ Rata - rata $<76$ & Positif \\
\hline 3. & $38 \leq$ Rata - rata $<57$ & Negatif \\
\hline 4. & $19 \leq$ Rata - rata $<38$ & Sangat Negatif \\
\hline
\end{tabular}

\section{HASIL PENELITIAN DAN PEMBAHASAN}

1. Skor Angket Guru Matematika Idola

Tabel 5

Descriptive Statistics Angket Guru Idola

\begin{tabular}{|l|l|l|l|l|l|}
\hline & N & Minimum & Maximum & Mean & Std. Deviation \\
\hline Guru_Idola & 27 & 39 & 72 & 51.89 & 8.040 \\
Valid N (listwise) & 27 & & & & \\
\hline
\end{tabular}

Dari data olah SPSS hasil angket persepsi di atas menunjukkan nilai rata-rata sebesar 51.89, berdasarkan tabel 3.6 (bab III) maka dapat dikatakan bahwa rata-rata 
siswa kelas X-1 berpersepsi negatif terhadap guru matematika kelas mereka. Artinya guru matematika kelas mereka bukan sosok guru matematika idola bagi sebagian besar siswa dengan 23 siswa berpersepsi negatif dan 4 sisanya berpresepsi positif dari total sejumlah 27 siswa yang diteliti.

\section{Skor Angket Motivasi}

Tabel 6

Descriptive Statistics Motivasi Belajar

\begin{tabular}{|l|l|l|l|l|l|}
\hline & N & Minimum & Maximum & Mean & $\begin{array}{l}\text { Std. } \\
\text { Deviation }\end{array}$ \\
\hline Motivasi_belajar & 27 & 23 & 76 & 50.19 & 14.807 \\
Valid N (listwise) & 27 & & & & \\
\hline
\end{tabular}

Dari data olah SPSS hasil angket motivasi di atas menunjukkan nilai ratarata sebesar 50.19, berdasarkan tabel 3.6 (bab III) maka dapat dikatakan bahwa ratarata motivasi belajar siswa negatif. Artinya rata-rata siswa kelas X-1 tidak memiliki motivasi untuk belajar matematika. Hasil angket menunjukkan hanya terdapat 8 siswa yang memiliki motivasi belajar matematika dan 19 siswa sisanya tidak memiliki motivasi untuk belajar matematika.

\section{Data Hasil Belajar Siswa}

Data hasil belajar merupakan data kuantitatif dari hasil nilai Ujian Semester I siswa kelas X-1 setelah digabungkan dengan nilai ulangan harian, nilai tugas dan nilai aktifitas. Penghitungan dilakukan menggunakan SPSS 16.0 analizedescriptive statistics-deskcriptives menghasilkan data sebagai berikut:

Tabel. 7

Descriptive Statistics Nilai Hasil Belajar Siawa

\begin{tabular}{|l|r|r|r|r|r|}
\hline & N & Minimum & Maximum & Mean & Std. Deviation \\
\hline skor_hasil_belajar & 27 & 75 & 83 & 77.52 & 1.988 \\
Valid N (listwise) & 27 & & & & \\
\hline
\end{tabular}

Dari data olah SPSS hasil belajar siswa pada semester I di atas, dapat dijelaskan bahwa secara statistik dideskripsikan nilai rata-rata siswa kelas X-1 telah memenuhi KKM yang ditetapkan sekolah. Sebab secara keseluruhan tidak ada 
siswa yang nilainya dibawah KKM sekolah. Namun hanya berada di kisaran nilai rata-rata.

Sebelum melakukan pembahasan pada penelitian deskriptif kuantitatif terlebih dulu dilakukan uji analisi data. Pada penelitian ini dilakukan uji asumsi klasik dan uji hipotesis untuk menganalisis data hasil penelitian. Setelah dilakukan uji asumsi klasik menunjukkan bahwa data layak untuk digunakan. Sebab hasil uji normalitas menunjukkan bahwa residual terdistribusi secara normal, uji autokerelasipun menunjukkan bahwa tidak terdapat korelasi negatif, uji heterokedastositas menunjukkan bahwa telah terjadi heteroskedastisitas pada model regresi sehingga model regresi layak dipakai, dan pada hasil uji multikolinieritas pun menunjukkan besarnya VIP masing-masing variabel lebih kecil dari 10 dan mempunyai angka toleran lebih besar dari 0.10 sehingga dapat disimpulkan tidak terdapat multikolinieritas.

Pada uji hipotesis, setelah dilakukan analisis regresi jalur mennunjukkan didapatkanya didapatkan dua persamaan sebagi berikut:

$\underline{\text { Persamaan I }}$

$$
\begin{gathered}
\mathrm{Y} 1(\mathrm{I})=-7.196+0.600 \mathrm{X} 1+\mathrm{e} 1 \ldots 1 \\
(0.646)^{* *}(0.001)^{* *}
\end{gathered}
$$

Penjelasan dari analisis regresi jalur 1:

a : konstanta sebesar -7.196 menunjukkan nilai negatif artinya jika variabel guru matematika idola konstan maka motivasi belajar matematika menurun.

b1 : koefisien regresi variabel guru matematika idola sebesar 0.600 menunjukkan bahwa variabel guru matematika idola berkontribusi positif terhadap motivasi belajar siswa, ini berarti jika variabel guru matematika idola ditingkatkan maka motivasi belajar siswa akan meningkat.

$\underline{\text { Persamaan II }}$

$$
\begin{gathered}
\mathrm{Y} 2(\mathrm{II})= \\
(0.000)^{* *}(0.489)^{* *}(0.861)^{* *}
\end{gathered}
$$

Penjelasan dari analisis regresi jalur 1:

A : konstanta sebesar 75.544 menunjukkan nilai positif artinya variabel guru matematika idola, Motivasi belajar sudah berjalan dengan baik 
b1 : koefisien regresi variabel guru matematika idola sebesar 0.177 menunjukkan bahwa variabel guru matematika idola berkontribusi positif terhadap motivasi belajar siswa. ini berarti jika variabel Guru matematika idola ditingkatkan maka Hasil belajar siswa akan meningkat.

Pada uji t menunjukkan hasil sebagi berikut:

1. Hasil regresi persamaan pertama menunjukkan bahwa $t_{\text {hitung variabel guru }}$ matematika idola sebesar 3.755 dengan nilai signifikansi sebesar 0.001, karena nilai signifikansi $>\alpha=0.05$ maka terdapat pengaruh yang signifikansi dari variabel guru matematika idola terhadap motivasi belajar matematika.

2. Hasil regresi persamaan kedua menunjukkan bahwa $t_{\text {hitungvariabel }}$ gurumatematika idola sebesar 0.703 dengan nilai signifikansi sebesar 0.489 , karena nilai signifikansi sebesar $0.489>\alpha=0.05$ maka terdapat pengaruh yang tidak signifikan dari variabel guru matematika terhadap hasil belajar siswa

3. Hasil regresi persamaan kedua menunjukkan bahwa $t_{\text {hitungvariabel motivasi }}$ belajar matematika sebesar 3.755 dengan nilai signifikansi sebesar $0.861>\alpha=$ 0.05 maka terdapat pengaruh yang tidak signifikansi dari motivasi belajar siswa terhadap hasil belajar siswa.

Sedangkan pada uji F menunjukkan hasil bahwa guru matematika idola dan motivasi belajar siswa mempunyai $F_{\text {hitung }} 0.294$ dengan nilai signifikansi sebesar $0.748>\alpha=0.05$ sehingga secara simultan variabel guru matematika idola dan motivasi belajar siswa berkontribusi negatif dan tidak signifikan terhadap hasil belajar siswa. Hal ini disebabkan karena data hasil angket menunjukkan bahwa guru matematika kelas tidak menajdi guru matematika idola bagi siswa, sehingga siswa pun tidak memiliki motivasi belajar matematika.

Uji Koefisien Determinasi $\left(R^{2}\right)$ diperoleh melalui:
a. e1 persamaan 1
b. e1 persamaan 2
Maka nilai koefisien deter-minasi $\left(R^{2}\right)$
$\mathrm{e} 1=\sqrt{1-0.361}$
$\mathrm{e} 1=\sqrt{0.639}$
$\mathrm{el}=0.7994$
$\mathrm{e} 1=\sqrt{1-R_{2}^{2}}$
$\mathrm{e} 1=\sqrt{1-R_{2}^{2}}$
e1 $=\sqrt{1-0.24}$
$\mathrm{e} 1=\sqrt{0.76}$
$\mathrm{e} 2=0.872$
$R^{2}=1-\left(R_{1}^{2} \times R_{2}^{2}\right)$
$R^{2}=1-(0.7994)^{2} \times(0.872)^{2}$
$R^{2}=1-(0.64 \times 0.7604)$
$R^{2}=1-(0.49)$
$R^{2}=0.51$
$R=\sqrt{0.51}=0.714=71,4 \%$ 
Nilai R square total 0.714 , artinya variabel guru matematika idola dengan motivasi belajar siswa sebagai variabel intervening berpengaruh sebesar $71.4 \%$ dan sisanya $38.6 \%$ dijelaskan faktor lain.

Adapun hasil Analisis Korelasi menunjukkan bahwa:

1. Korelasi guru matematika idola terhadap motivasi belajar siswa

Berdasarkan hasil analisis angka korelasi variabel guru matematika idola terhadap motivasi belajar siswa sebesar 0.600 sehingga hubungan variabel guru matematika idola terhadap motivasi belajar siswa cukup kuat dan searah (karena hasil positif). Searah artinya jika motivasi belajar siswa meningkat maka pengaruh positif guru matematika idola terhadap siswa meningkat. Korelasi dua variabel bersifat signifikan karena angka signififkan sebesar $0.001<\alpha=0.05$.

2. Korelasi motivasi belajar siswa terhadap hasil belajar siswa

Berdasarkan hasil analisis diperoleh angka korelasi variabel motivasi belajar siswa sebesar 0.062 sehingga hubungan variabel motivasi belajar siswa teerhadap hasil belajar siswa tidak kuat dan searah (karena hasil positif). Searah artinya jika hasil belajar siswa meningkat maka motivasi belajar pun pasti meningkat. Korelasi dua varariabel bersifat tidak signifikan karena signifikan sebesar $0.759>\alpha=0.05$.

3. Korelasi Guru Matematika idola terhadap hasil belajar siswa

Berdasarkan hasil analisis diperoleh angka korelasi variabel motivasi belajar siswa sebesar 0.151 sehingga hubungan variabel korelasi guru matematika idola terhadap hasil belajar siswa tidak kuat dan searah (karena hasil positif). Searah artinya jika hasil belajar siswa meningkat maka Guru matematika idola pun pasti meningkat. Korelasi dua varariabel bersifat tidak signifikan karena signifikan sebesar $0.151>\alpha=0.454$.

\section{Pengaruh Langsung, Tidak Langsung}

1. Pengaruh Langsung

a. Pengaruh variabel guru matematika idola $(\mathrm{X})$ terhadap motivasi belajar matematika (Y1). berdasarkan hasil pengujian regresi linier sederhana persamaan pertama diperoleh koefisien regresi variabel guru idola sebesar 
0.600 sehingga guru matematika idola berkontribusi signifikan terhadap motivasi belajar matematika. Sehingga hipotesis 1 menyatakan terdapat kontribusi yang signifikan antara variabel guru matematika idola terhadap motivasi belajar siswa dan terbukti dalam penelitian ini.

b. Pengaruh variabel motivasi belajar (Y1) terhadap hasil belajar siswa (Y2). Berdasarkan hasil pengujian regresi linier berganda persamaan kedua diperoleh koefisien variabel motivasi belajar sebesar -0.44 sehingga hasil belajar berkontribusi tidak signifikan terhadap hasil belajar siswa. sehingga hipotesis 2 menyatakan tidak terdapat kontribusi yang signifikan antara motivasi belajar dengan hasil belajar siswa.

c. Pengaruh variabel guru matematika idola $(\mathrm{X})$ terhadap hasil belajar siswa (Y2). Berdasar hasil pengujian regresi linier berganda persamaan kedua diperoleh koefisien 0.600 sehingga guru matematika idola berkontribusi tidak signifikan terhadap hasil belajar siswa. Sehinggan hipotesis 3 menyatakan tidak terdapat kontribusi yang signifikan antara guru matematika idola terhadap hasil belajar siswa.

2. Pengaruh Tidak Langsung

Pengaruh guru matematika idola terhadap hasil belajar siswa secara tidak langsung melalui motivasi belajar siswa. Berdasarkan hasil pengujian regresi linier berganda persamaan pertama dan kedua menunjukkan kontribusi guru matematika idola terhadap hasil belajar siswa secara tidak langsung melalui motivasi belajar siswa diperoleh hasil dari perkalian pengaruh variabel guru matematika idola terhadap motivasi belajar siswa dengan pengaruh motivasi belajar terhadap hasil belajar siswa $(0.600 \times(-0.44)=-0.264)$. Hasil ini menunjukkan bahwa pengaruh guru matematika idola terhadap hasil belajar siswa secara tidak langsung melalui motivasi belajar siswa, kontribusinya lebih kecil dibandingkan dengan tidak melalui motivasi belajar siswa sebagai variabel intervening karena koefisien regresi variabel guru matematika idola yang berkontribusi langsung terhadap hasil belajar siswa sebesar 0.177 lebih besar dibandingkan dengan koefisien regresi pengaruh variabel guru matematika 
idola terhadap hasil belajar siswa secara tidak langsung melalui motivasi belajar siswa sebesar -0.264 .

Kontribusi langsung dan tidak langsung dapat dilihat:

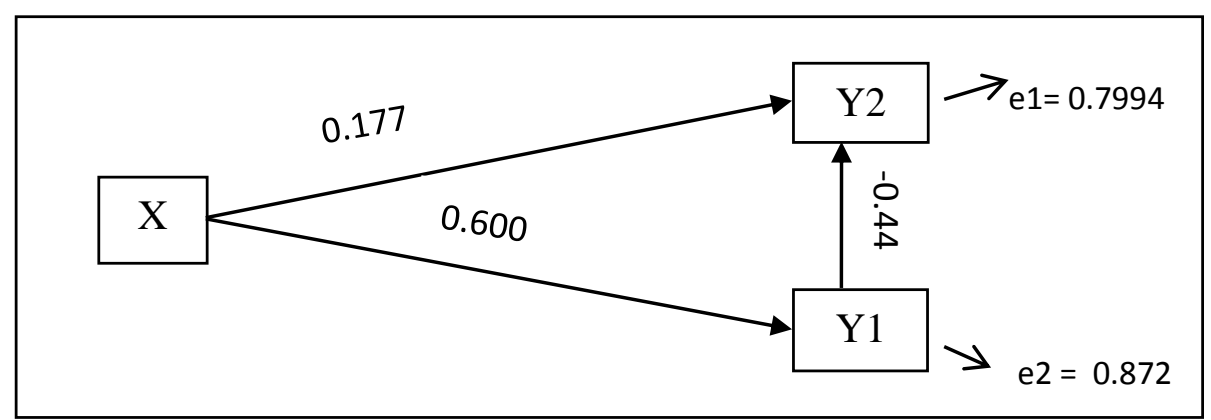

Gambar 4.3: Hasil kontribusi langsung dan tak langsung

\section{SIMPULAN}

Berdasarkan uraian pembahasan pada bab IV yang ditinjau dari rumusan masalah dan tujuan penelitian pada bab I. Maka, peneliti dapat menarik kesimpulan dari hasil penelitian tersebut bahwa:

1. Terdapat pengaruh yang signifikan variabel guru matematika idola terhadap motivasi belajar siswa. Hasil pengujian regresi linier diperoleh koefisien sebesar 0.600 sehingga guru matematika idola berkontribusi signifikan terhadap motivasi belajar siswa. Artinya jika variabel guru matematika idola ditingkatkan maka motivasi belajar siswa akan meningkat.

2. Tidak terdapat pengaruh yang signifikan variabel guru matematika idola terhadap hasil belajar siswa di sebabkan hasil uji regresi menunjukkan nilai signifikasi sebesar $0.489>\alpha=0.05$. namun guru matematika idola berkontribusi positif terhadap motivasi belajar mstematika sebab hasil koofisien menunjukkan nilai positif sebesar 0.703. Ini berarti jika variabel guru matematika idola ditingkatkan atau jika siswa mengidolakan guru matematika kelas mereka maka hasil belajar siswa akan meningkat.

3. Pengaruh guru matematika idola terhadap hasil belajar siswa secara tidak langsung melalui motivasi belajar siswa kontribusinya lebih kecil dibandingkan dengan tidak melalui motivasi belajar siswa sebagai variabel intervening, karena koefisien regresi variabel guru matematika idola yang berkontribusi langsung terhadap hasil belajar siswa sebesar 0.177 lebih besar dibandingkan 
dengan koefisien regresi pengaruh variabel guru matematika idola terhadap hasil belajar siswa secara tidak langsung melalui motivasi belajar siswa sebesar -0.264 .

\section{DAFTAR PUSTAKA}

Alwi, Hasan. 2005. Kamus Besar Bahasa Indonesia. Jakarta: Balai Pustaka

Arikunto, Suharsimi. 2003. Dasar-Dasar Evaluasi Pendidikan. Jakarta: Bumi Aksara

Arikunto, Suharsimi. 2010. Prosedur Penelitian Suatu Pendekatan Praktik. Jakarta: Rineka Cipta.

Depdiknas. 2003. Kurikulum Berbasis Kompetensi. Jakarta.

Dimyati. 2012. Psikologi Pendidikan.Jakarta: Rosdakarya.

Dimyati dan Mudjiono. 2009. Belajar dan Pembelajaran. Jakarta: Rineka Cipta.

Ghozali, Imam. 2011. Aplikasi Analisis Multivariate Dengan Program SPSS. Badan Penerbit Undip Semarang.

Gulo, M. 2002. Metodologi Penelitian. Pt. Grasindo Jakarta

Hamalik, Omar. 2000. Psikologi belajar dan mengajar. Bandung: PT. Sinar Baru Algensindo.

Isro'iyah, Nur Laili. 2012. Peningkatan Hasil Belajar Matematika Siswa SMP Muhammadiyah 13 Surabaya Kelas VIII Melalui Pembelajaran Kooperatif Tipe Tai (Team Assisted Individualization): UMS. Skripsi tidak dipublikasikan.

Jalaludin. 2001. Teologi Pendidikan. Jakarta: PT.Raja Grafindo Persada.

Margono, Bambang Dwi. 2010. Profil Guru Idola dan Pengaruhnya dalam Proses Pembelajaran Siswa pada Sekolah Dasar Muhammadiyah Polan Harjo Kabupaten Klaten: UMS. Skripsi tidak dipublikasikan.

Purwanto. 2011. Evaluasi Hasil Belajar. Yogyakarta: Pustaka Pelajar

Romadhon, Bayu. 2014. Korelasi Persepsi Siswa Terhadap Kegiatan Pembelajaran Dan Hasil Belajar Matematika Siswa Kelas X Tkj (Teknik Komputer Jaringan) 1 Smk Pgri Kota Mojokerto: UMSurabaya. Skripsi tidak dipublikasikan.

Sardiman. 2012. Interaksi \& Motivasi Belajar Mengajar. Jakarta: PT Raja Grafindo Persada.

Shoffan. Shoffa. 2013. Kontribusi Kepemimpinan, Budaya Organisasi Dan Komitmen Terhadap Kepuasan Kerja Secara Tidak Langsung Melalui Kinerja Karyawan Di Universitas Muhammadiyah Surabaya: UMS. Tesis tidak dipublikasikan

Soemantri, Sandha. 2012. Korelasi Antara Komposisi Peserta Tes Dengan Kecemasan Siswa, SertaPengaruhnya Terhadap Prestasi Belajar Matematika: UMSurabaya. Skripsi tidak dipublikasikan.

Sudjana. 1996. Metoda Statistika. Bandung: Tarsito.

Sugiyono. 2011. Metode Penelitian Kuantitatif Kualitatif dan $R \&$ D. Bandung: Alfabeta.

Suparlan. 2008. Menjadi Guru Efektif. Yogyakarta: HIKAYAT Publishing. 
Susanto, Amin. 1999. Pembelajaran Sains dan Aplikasinya. Jakarta: UNJ Press. UURI Nomor 20 tahun 2003 tentang Sistem Pendidikan Nasiona. Citra Umbara: Bandung

Wiasworo, Erwin. 2014. Rahasia Menjadi Guru Idola. Yogyakarta: AR RUZZ MEDIA. 